\title{
DAS FUNÇÕES RECONSTITUTIVA E PUNITIVA DA RESPONSABILIDADE CIVIL: PROPOSTAS DE REFORMA DO CÓDIGO CIVIL PORTUGUÊS
}

\author{
DISGORGEMENT DAMAGES AND PUNITIVE DAMAGES: A PROPOSAL TO REFORM THE \\ PORTUGUESE CIVIL CODE
}

\author{
Henrique Sousa Antunes ${ }^{1}$
}

RESUMO: O tempo vem demonstrando que nos sistemas jurídicos romano-germânicos o resgate do lucro ilícito carece de uma resposta adequada e eficaz. Em vários instrumentos, nomeadamente de direito europeu, o dever de indemnizar é concebido como um remédio que transfere o lucro para o lesado. Tivemos oportunidade de defender que a indemnização é, na verdade, o lugar natural para a restituição do lucro ilícito, mas, de qualquer forma, a emergência das novas soluções legislativas tornam essa resposta evidente. De igual modo, o espaço próprio do direito civil exige a restrição das sanções administrativas, excluindo essa intervenção do direito público quando os bens ofendidos são de natureza exclusiva ou prevalentemente individual. Justificar-se-á, nesses casos, a aplicação alternativa de uma pena privada, repondo a dignidade do direito subjetivo violado. Este enquadramento reclama uma reforma do Código Civil português, o que aqui se propõe.

Palavras-chave: Lucro ilícito. Restituição. Indemnização. Contraordenações. Pena privada.

\begin{abstract}
Over time we have come to see that Roman-Germanic legal systems lack an adequate and effective response for recovering illegal gains. In several instruments, in particular of European Law, the duty to indemnify is designed as a remedy that transfers the profit to the injured party. We have had the opportunity to argue that compensation is, indeed, the natural place for restoring illegal gains, but, in any case, the emergence of new legislative solutions makes such a response clear. Equally, the sphere of civil law itself requires that administrative sanctions be restricted, and this public law intervention is excluded when the harmed goods are exclusively or predominantly individual in character. In such cases, the application, instead, of a private penalty will be justified, restoring the dignity of the subjective right breached. This framework requires a reform of the Portuguese Civil Code, which is what is being proposed here.
\end{abstract}

Keywords: Illegal profits. Restitution. Damages. Administrative offences. Punitive damages.

Sumário: 1. Introdução. 2. O resgate do lucro ilícito. 3. A pena privada. 4. Propostas de reforma do Código Civil português. 5. Conclusão. 6. Referências.

\footnotetext{
${ }^{1}$ Professor Associado da Escola de Lisboa da Faculdade de Direito da Universidade Católica Portuguesa, instituição onde se doutorou em 2010. Leciona na área do Direito Privado, regendo Direito das Obrigações, Direitos Reais e Direito do Consumo. Integra vários grupos de trabalho internacionais. Publicou artigos e monografias sobre temas diversos, destacando-se a responsabilidade civil, a tutela coletiva dos direitos, o direito das fundações e os direitos reais. Foi Diretor da Escola de Lisboa da Faculdade de Direito da UCP entre 2011 e 2013.
} 


\section{INTRODUÇÃO}

A discussão sobre a função punitiva da responsabilidade civil está indelevelmente marcada pelo pecado original da responsabilidade. No início dos tempos, a reparação e a punição constituíam uma mesma resposta à ofensa praticada. Que a conduta de um agente pudesse ser sancionada com um fim diverso da retribuição movida pelo mal imputado àquele comportamento pressupôs a sofisticação do pensamento jurídico. A responsabilidade civil emancipou-se da responsabilidade penal e, ciosa da sua alforria, rejeita, na pureza dos conceitos, uma diluição de identidades ${ }^{2}$.

A justificação para a sobrevivência ou a emergência de regimes punitivos nos sistemas jurídicos anglo-saxónicos e, esparsamente, nos direitos da Europa continental aparece diluída nas circunstâncias do momento que os ditou. Cremos que, neste contexto, mais importante do que perceber os motivos da sua origem é reconhecer a sua existência ${ }^{3}$.

As águas da reflexão são turvas e, no entanto, o debate é urgente ${ }^{4}$. Eis os pontos cardeais destas linhas. A restituição do lucro vem sendo trazida à análise sobre a pertinência da inclusão de uma dimensão punitiva entre os efeitos da responsabilidade civil. Como veremos, sem fundamento. Do mesmo modo, a seriedade do labor jurídico não é compatível com declarações de rejeição epidérmica da função punitiva assinalada. São as exigências da necessidade humana que condicionam os paradigmas do direito.

Eis, então, as perguntas que orientam o nosso percurso: é possível incluir o resgate do lucro ilícito no dever de indemnizar? Constitui solução desejável a previsão de penas privadas como sanção de um facto ilícito?

\section{O RESGATE DO LUCRO ILÍCITO}

\footnotetext{
${ }^{2}$ Os preceitos ou regimes legais sem indicação diversa no texto são de direito português. Encontra-se uma síntese da evolução histórica da responsabilidade civil em ALMEIDA CosTA, Mário Júlio de. Direito das Obrigações, 12. a edição. Coimbra: Almedina, 2009, pp. 524 e ss.

3 Sobre a premência do debate em diálogo de direito comparado, veja-se, por exemplo, Gomes, Júlio. Uma função punitiva para a responsabilidade civil e uma função reparatória para a responsabilidade penal. Revista de Direito e Economia, ano XV (1989), pp. 105 e ss.

${ }^{4}$ Em perspectiva diversa, rejeitando a legitimidade de danos punitivos, consulte-se MIRANDA BARBOSA, Ana Mafalda Castanheira Neves de. Lições de Responsabilidade Civil. Cascais: Princípia, 2017, pp. 41 e ss.
} 


\title{
Revista IBERC
}

v.2, n. 1, p. 01-23, jan.-abr./2019

www.responsabilidadecivil.org

O conceito de indemnização tem assentado na reconstituição da situação hipotética do lesado. Trata-se de ressarcir os danos patrimoniais e não patrimoniais da pessoa ofendida pela lesão. Em virtude da conceptualização talhada pela evolução histórica, os efeitos do facto determinante da responsabilidade na esfera do lesante são apartados da obrigação de indemnizar.

E, no entanto, outra vem sendo a abordagem do legislador contemporâneo, destacando-se, a esse respeito, o legislador europeu. Servem de referência a Diretiva 2004/48/CE do Parlamento Europeu e do Conselho, de 29 de abril de 2004, relativa ao respeito dos direitos de propriedade intelectual, e a Diretiva (UE) 2016/943, de 8 de junho de 2016, relativa à proteção de know-how e de informações comerciais confidenciais (segredos comerciais) contra a sua aquisição, utilização e divulgação ilegais ${ }^{5}$.

No artigo $13 .^{\circ}$, n. ${ }^{\circ}$, da Diretiva 2004/48 lê-se, acerca da indemnização por perdas e danos (epígrafe da norma):

Os Estados-Membros devem assegurar que, a pedido da parte lesada, as autoridades judiciais competentes ordenem ao infrator que, sabendo-o ou tendo motivos razoáveis para o saber, tenha desenvolvido uma atividade ilícita, pague ao titular do direito uma indemnização por perdas e danos adequada ao prejuízo por este efetivamente sofrido devido à violação». Ora, nos termos da alínea a) dessa norma, os lucros indevidos obtidos pelo infrator constituem uma consequência económica negativa relevante, um dado que vincula as autoridades judiciais na fixação do montante da indemnização por perdas e danos. Ou, como se descobre no considerando 26 da Diretiva: «(...) o montante das indemnizações por perdas e danos a conceder ao titular deverá ter em conta todos os aspetos adequados, como os lucros cessantes para o titular, ou os lucros indevidamente obtidos pelo infrator (...).

A fórmula é replicada na Diretiva (UE) 2016/943, com a seguinte justificação (considerando 30):

\begin{abstract}
A fim de evitar que uma pessoa que adquira, utilize ou divulgue um segredo comercial, com conhecimento de causa ou com motivos razoáveis para ter esse conhecimento, possa beneficiar dessa conduta, e de assegurar que o titular do segredo comercial lesado seja, na medida do possível, colocado na posição em que estaria caso essa conduta não tivesse ocorrido, é necessário prever uma compensação adequada do prejuízo sofrido como resultado dessa conduta ilegal. O montante da indemnização concedida ao titular lesado do segredo comercial deverá ter em consideração todos os fatores adequados, como a perda de rendimentos do titular do segredo comercial ou os lucros indevidos do infrator (...)». Na parte dispositiva, constituem os lucros do lesante uma consequência económica negativa atendível na fixação
\end{abstract}

\footnotetext{
${ }^{5}$ Publicadas no "Jornal Oficial da União Europeia”, respetivamente, L 195, de 2 de junho de 2004, pp. 16 a 25, e L 157, de 15 de junho de 2016, pp. 1 a 18.
}

Revista IBERC, Minas Gerais, v.2, n.1, p. 01-23, jan.-abr./2019 


\section{Revista IBERC}

v.2, n. 1, p. 01-23, jan.-abr./2019

www.responsabilidadecivil.org

da indemnização, prevendo o legislador que os Estados-Membros limitem «a responsabilidade dos empregados perante os respetivos empregadores por prejuízos causados em virtude da aquisição, utilização ou divulgação ilegais de um segredo comercial do empregador caso o seu comportamento não tenha sido doloso (artigo $14 .^{\circ}, \mathrm{n} .^{\circ}$ s 1 e 2 ).

Em qualquer dos regimes, o legislador permitiu que a indemnização pudesse assumir a natureza de um montante fixo, correspondente à remuneração devida se a autorização houvesse sido prestada. Essa quantia constitui, no entanto, um valor mínimo.

As soluções representam, apenas, um pragmatismo na elaboração da lei, subordinando-se o conceito de indemnização às finalidades prosseguidas, ou constituem, ainda, uma manifestação desse conceito? Temos defendido que a noção de indemnização dada pelo direito português é compatível com o caminho que os regimes atrás referidos procuram trilhar. Afinal, dá-se cumprimento a uma dimensão relacional que anima a indemnização ${ }^{6}$. Reconheça-se, porém, que, em nossa opinião, o resgate do proveito obtido pelo agente acompanha até o entendimento mais tradicional sobre a indemnização, considerando que o lucro ilicitamente obtido constitui um dano não patrimonial autónomo sofrido pelo lesado.

Escrevemos, outrora:

As insuficiências do enriquecimento sem causa, quanto ao seu objeto e a respeito das suas consequências, a artificialidade do recurso à gestão de negócios imprópria, e, porventura, os seus efeitos perversos, a limitação da aplicação analógica das regras da posse, a amplitude com que a indemnização dos danos não patrimoniais foi acolhida no direito português, adaptável à evolução das circunstâncias sociais, o fim de satisfazer o lesado que àquela é reconhecida, reagindo à infirmação do seu direito, a natureza do bem que é ofendido, o sentimento de justiça, deve habilitar o juiz, nesta sede, a restituir ao lesante as receitas líquidas imputáveis ao seu comportamento. Em situações de elevada censurabilidade, admite-se a aplicação do critério das receitas brutas ${ }^{7}$.

Seja como for, é dificilmente sustentável que um conceito clássico de indemnização possa ser imune às alterações legislativas que, entretanto, vão ocorrendo. A inclusão do lucro do lesante no juízo de indemnização não é justificável pela especificidade das matérias

\footnotetext{
${ }^{6}$ Considere-se que o artigo $562 .{ }^{\circ}$ do Código Civil impõe ao lesante o dever de recriar a situação hipotética que a sua intervenção impossibilitou. Então, retomando o nosso pensamento, «essa realidade alternativa tem, necessariamente, de compreender a posição do agente. Se o lesante obteve um benefício patrimonial com o seu comportamento, é uma ficção dizer-se que a restituição escapa à reconstituição da situação que existiria". SOUSA ANTUNES, Henrique. Das funções reconstitutiva e punitiva da responsabilidade civil extracontratual. In CARDoso Guedes, Agostinho; PINTo OliveIRA, Nuno Manuel (Org.). Colóquio de Direito Civil de Santo Tirso - O Código Civil 50 anos depois: balanço e perspetivas. Coimbra: Almedina, 2017, p. 492.

${ }^{7}$ Sousa Antunes, Henrique. Da Inclusão do Lucro llícito e de Efeitos Punitivos entre as Consequências da Responsabilidade Civil Extracontratual: a sua Legitimação pelo Dano. Coimbra: Coimbra Editora, 2011, p. 651.
} 


\section{Revista IBERC}

v.2, n. 1, p. 01-23, jan.-abr./2019

www.responsabilidadecivil.org

legisladas, antes constitui uma opção de política legislativa motivada pela prevenção de comportamentos parasitários, de natureza, necessariamente, geral. Aliás, num sistema jurídico em que a intervenção de outras disciplinas normativas se revela, certamente imprópria, mas também ineficaz. O direito português das contraordenações permite que o lesante conserve 0 lucro ilícito obtido, na medida em que a elevação da coima em razão do benefício económico do agente não pode exceder um terço do limite máximo estabelecido por lei (artigo $18 .^{\circ}, \mathrm{n} .^{\circ} 2$, do regime geral das contraordenações - Decreto-Lei n. ${ }^{\circ}$ 433/82, de 27 de outubro).

Neste sentido, a unidade do sistema jurídico impõe a revisão da noção de indemnização. É insustentável que o ordenamento acolha regimes parcelares sem atender à expressão universal da censura ao desrespeito consciente pela decisão alheia sobre o destino económico dos bens utilizados. Neste sentido, é especialmente significativo o projeto de reforma da responsabilidade civil em França (março de 2017), estatuindo entre os efeitos da responsabilidade, uma pena aplicável nos termos da seguinte previsão geral (artigo 1266-1, alínea1): «En matière extracontractuelle, lorsque l'auteur du dommage a délibérément commis une faute en vue d'obtenir un gain ou une économie, le juge peut le condamner, à la demande de la victime ou du ministère public et par une décision spécialement motivée, au paiement d'une amende civile». Está clara a vocação universal da repressão do lucro ilícito do lesante pela responsabilidade civil.

Entretanto, que não se duvide da ausência de qualquer efeito punitivo nas opções do legislador europeu. Assim é, em razão da natureza do resgate do lucro ilícito: o lesante é colocado na situação em que estaria se não tivesse praticado a lesão. Assim é, também, porque o legislador expressamente o declara.

\section{A PENA PRIVADA}

E quanto à atribuição de uma dimensão punitiva à responsabilidade civil? O exercício de um poder punitivo sobre uma pessoa em benefício de outra pessoa parece ideia adversa à sujeição das relações jurídico-privadas a uma justiça corretiva, destinada a repor o equilíbrio entre as partes. Ao longo da história, a punição converteu-se num instrumento da coletividade destinado a sancionar a ofensa de interesses públicos. Só a tutela da comunidade justificaria a afetação da liberdade individual ou da integralidade patrimonial em medida que excedesse a correção dos desequilíbrios gerados pelo comportamento do lesante.

A superação do paradigma de um castigo às mãos do outro, certamente pela substituição do exercício da tutela privada pela heterotutela, mas também pela demarcação 


\section{Revista IBERC}

v.2, n. 1, p. 01-23, jan.-abr./2019

www.responsabilidadecivil.org

progressiva das fronteiras entre o interesse público e o interesse privado, é celebrada como uma conquista do pensamento jurídico. As penas privadas constituiriam, assim, manifestações de desforço, de desagravo, memórias de um tempo passado.

Defender a possibilidade de a responsabilidade civil gerar efeitos punitivos parece a manifestação de uma impropriedade técnico-jurídica, um erro primário de um jurista impreparado. Assim na Europa continental. A proibição reiterada da condenação em punitive damages pelo legislador europeu exemplifica que, mais do que as razões ligadas às especificidades de certo ordenamento jurídico, a afirmação constitui uma verdade intocável. A rejeição é replicada de forma acrítica: nem sequer se equaciona a bondade da medida, depurada das desvantagens que as características de outro sistema judicial, como o norteamericano, impliquem.

Veja-se o que sucede na Recomendação da Comissão Europeia de 11 de junho de 2013, sobre os princípios comuns que devem reger os mecanismos de tutela coletiva inibitórios e indemnizatórios dos Estados-Membros aplicáveis às violações de direitos garantidos pelo direito da União (2013/396/EU) $)^{8}$. Pretende-se facilitar o acesso à justiça e garantir um nível elevado de proteção do consumidor (considerando 1). Se, à luz das finalidades declaradas, a existência de danos em massa motivaria a revisão do papel tradicional conferido à indemnização, o considerando 15 justifica a proibição da condenação em punitive damages com a prevenção de "uma cultura de litígios abusivos". E, no entanto, as tradições jurídicas da maioria dos Estados-Membros (parte final do considerando) são utilizadas como um conforto argumentativo. Aliás, no Relatório da Comissão sobre a aplicação da Recomendação (apresentado em 25 de janeiro de $2018{ }^{9}$ ) lê-se, a respeito da proibição das indemnizações punitivas estabelecida no princípio 31 :

O conceito de excesso de compensação por danos punitivos é, de modo geral, estranho à maioria dos sistemas jurídicos dos Estados-Membros. $\mathrm{O}$ convite à apresentação de informações não revelou qualquer caso de danos punitivos solicitados ou concedidos em ações de tutela coletiva. Deste modo, concluiu-se que não havia necessidade de normas especiais para as ações de tutela coletiva ${ }^{10}$.

Outro exemplo de uma opção tomada sem a ponderação devida acerca da adequação dos instrumentos utilizados para a tutela prosseguida encontramos na Diretiva 2014/104/UE do Parlamento Europeu e do Conselho, de 26 de novembro de 2014, relativa a certas regras que regem as ações de indemnização no âmbito do direito nacional por infração às disposições do

\footnotetext{
${ }^{8}$ Publicada no “Jornal Oficial da União Europeia”, L 201/60, de 26 de julho de 2013, pp. 60 a 65.

${ }^{9} \mathrm{COM}(2018) 40$ final.

${ }^{10}$ P. 18.
} 


\title{
Revista IBERC
}

v.2, n. 1, p. 01-23, jan.-abr./2019

www.responsabilidadecivil.org

direito da concorrência dos Estados-Membros e da União Europeia ${ }^{11}$. Reconhecendo que a aplicação privada é uma condição de plena eficácia do direito da concorrência (considerando 3), limita aquela à indemnização dos danos sofridos. Descobre-se no considerando 13, parte final: «Sem prejuízo da reparação por perda de oportunidade, a reparação integral nos termos da presente diretiva não deverá conduzir a reparação excessiva, por meio de indemnizações punitivas, múltiplas ou outras». Neste sentido dispõe o artigo $3 .^{\circ}, n .{ }^{\circ} 3$, da referida Diretiva.

Saliente-se que, no percurso legislativo, o Livro Verde da Comissão sobre o tema (de 19 de dezembro de $2005^{12}$ ) abordou a restituição dos lucros ilícitos e a possibilidade de duplicação da indemnização, soluções que o Livro Branco (de 2 de abril de $2008^{13}$ ) viria a silenciar. Parece, a esse respeito, elucidativa a nota seguinte:

\begin{abstract}
A Comissão seguiu um (...) princípio orientador, nos termos do qual o quadro normativo necessário para assegurar maior eficácia às ações de indemnização por infração às regras comunitárias no domínio antitrust se deve basear numa abordagem genuinamente europeia. Consequentemente, as opções de política geral propostas (...) consistem em medidas equilibradas, assentes na cultura e tradições jurídicas europeias. (...) As medidas formuladas no presente Livro Branco são concebidas para criar um sistema eficaz de aplicação "privada", baseado em ações de indemnização que virão completar, sem substituir nem prejudicar, a ação dos poderes públicos neste domínio ${ }^{14}$.
\end{abstract}

O direito contemporâneo veio, no entanto, demonstrar que a abordagem histórica tem a si associada um risco de inversão metodológica evidente. Na atualidade, é, frequentemente, a punição a determinar o interesse público, em vez de este justificar a intervenção punitiva. $O$ legislador demitiu-se de uma análise prévia sobre a natureza dos interesses em presença. A disciplina das contraordenações é, porventura, o melhor sinal desse desconcerto. Em tempos, escrevemos sobre o destempero das contraordenações:

[...] o poder sancionatório da Administração excedeu os limites originais que o justificaram e inclui, agora, relações em que predomina o interesse privado. A lei beneficia a coletividade, destinando-lhe uma sanção que, no entanto, tem origem na ofensa de um bem primariamente individual. Ou seja, a justiça retributiva encontra fundamento na justiça corretiva, aplicando, contudo, uma lógica distributiva ao destino da sanção. Há uma incoerência intolerável do sistema que apenas pode ser corrigida convertendo o particular em beneficiário da pena. Desse modo, a justiça corretiva funcionaria como o alicerce e a abóboda da justiça retributiva que se entenda aplicável ${ }^{15}$.

\footnotetext{
${ }_{11}^{11}$ Publicada no “Jornal Oficial da União Europeia", L 349, de 5 de dezembro de 2014, pp. 1 a 19.

${ }^{12} \operatorname{COM}(2005) 672$.

${ }^{13} \operatorname{COM}(2008) 165$ final.

${ }^{14} \mathrm{Pp} .3$ e s.

${ }^{15}$ Sousa Antunes, Henrique. Da Inclusão do Lucro ..., p. 32 e s.
}

Revista IBERC, Minas Gerais, v.2, n.1, p. 01-23, jan.-abr./2019 


\section{Revista IBERC}

v.2, n. 1, p. 01-23, jan.-abr./2019

www.responsabilidadecivil.org

Que sentido faz reconhecer a existência de uma perturbação do interesse coletivo na afetação de direitos subjetivos sem tutela penal, e, desse modo, esgotando-se o interesse público na prevenção que uma pena privada é capaz de desempenhar? Em sentido paralelo à multiplicação de regimes contraordenacionais que sancionam a violação de um direito subjetivo de natureza patrimonial, como a propriedade intelectual ou a propriedade de coisa corpórea, ou um direito de personalidade, justificar-se-ia a revisão das penas privadas admitidas pelo legislador para a tutela do direito de crédito?

Pensa-se, em especial, nos juros moratórios (artigo 806. ${ }^{\circ}$ do Código Civil), na cláusula penal (artigos $810 .^{\circ}$ a $812 .^{\circ}$ do Código Civil) e na sanção pecuniária compulsória. Tome-se como exemplo esta última figura, prevista no artigo 829. ${ }^{\circ}$-A do Código Civil. No direito francês, onde descobrimos o antecedente do regime português, o credor recebe na integralidade 0 montante da sanção.

Argumente-se, ainda, com o espaço atribuído à indemnização dos danos não patrimoniais no direito português. $\mathrm{O}$ artigo $496 .^{\circ}$ do Código Civil é lido, geralmente, à luz de uma finalidade punitiva da disciplina.

Serão estas normas, e outros dispersas na lei civil, resquícios de um tempo primitivo, imperfeições que o legislador deve corrigir? Não. Constituem tão-só uma expressão da vinculação das sanções punitivas à natureza dos interesses prosseguidos, sempre que o legislador identifica a legitimidade, ou a necessidade, de instrumentos preventivos que acresçam à dinâmica própria de uma justiça corretiva.

Aquela vinculação está em conformidade com as exigências da existência humana. São palavras nossas: "As sanções privadas que, a respeito das consequências da aplicação daquele instituto, apresentem um efeito punitivo são legitimadas pelo dano. $O$ dano é a causa da sua estatuição, destinando-se o remédio, nuns casos a determiná-lo ou a preveni-lo, noutros a concretizar o direito do lesado ao desagravo, à vindicta» ${ }^{16}$.

Os regimes que convocámos, em expressão meramente exemplificativa, tornam urgente a reforma do sistema, o reposicionamento das contraordenações em face do direito civil $^{17}$. Vejamos.

$\mathrm{Na}$ sua origem, as contraordenações procuraram salvaguardar o funcionamento da atividade administrativa, designadamente na conformação do setor económico ${ }^{18}$. E nesses antecedentes, descobre o conceito o seu objeto fundamental. Tomando de empréstimo a

\footnotetext{
${ }^{16}$ SOUSA ANTUNES, Henrique. Da Inclusão do Lucro ..., p. 608.

${ }^{17}$ Eis o que aceita Pinto de Albuquerque, Paulo. Comentário do Regime Geral das Contraordenações à luz da Constituição da República e da Convenção Europeia dos Direitos do Homem. Lisboa: UCE, 2011, p. $12(\S 17)$.

${ }^{18}$ Veja-se, nomeadamente, SILVA DIAS, Augusto. Direito das Contraordenações. Coimbra: Almedina, 2018 (reimpressão), pp. 16 e ss.
} 


\section{Revista IBERC}

v.2, n. 1, p. 01-23, jan.-abr./2019

www.responsabilidadecivil.org

reflexão de Augusto SILVA DIAS, as contraordenações sancionam "comportamentos que atentam contra interesses de organização e funcionamento de setores da atividade económicosocial e/ou que frustram regras instituídas para a prevenção de perigos ${ }^{19}$. A fronteira é, em geral, traçada, em relação ao direito penal, descobrindo neste a retribuição das condutas que, nas palavras de Augusto SILVA DIAS, «atentam contra os fundamentos da sociedade, ancorados na ideia de reconhecimento recíproco de pessoas livres e iguais e nos bens jurídicos que a explicitam» ${ }^{20}$.

Acompanhando, ainda, o mesmo autor, «o território das contraordenações - e também de alguns setores do Direito Penal - é marcado não pela eticidade, aferida em função de um bem jurídico-penal, mas pela disfuncionalidade dos comportamentos, isto é, pela aptidão destes para provocar entropia no funcionamento de determinados subsistemas sociais, ou, se se preferir, para perturbar a vigência regular de interesses de ordenação de âmbitos da atividade social» ${ }^{21}$. Enfim, o fundamento das contraordenações «reside (...) na carência de regulação de uma dada atividade por necessidades de ordenação e/ou de prevenção institucional de perigos. Deverá ser esse o critério reitor para a criação de contraordenações, respaldado sempre em exigências de proporcionalidade» ${ }^{22}$.

Neste contexto, perdem as contraordenações legitimidade quando são utilizadas sem qualquer finalidade regulatória, procurando, tão-só, punir uma conduta que a censura do direito penal desconhece. Se há ofensa de bens jurídicos de natureza predominantemente individual, que espaço há para a sanção contraordenacional? Ou se admite a degeneração do conceito em razão de um desleixo legislativo, confortado por um "pau para toda a obra", ou trazemos seriedade à arquitetura do sistema jurídico.

Serve de paradigma o direito do trabalho, que nos acompanhou, para este efeito, noutro momento ${ }^{23}$. Hoje, toma-se como exemplo o Código do Direito de Autor e dos Direitos Conexos. Na distinção entre os fundamentos das contraordenações previstas nos n. ${ }^{\circ} \mathrm{s} 1$ e 2 do artigo $205 .^{\circ}$ desenha-se a delimitação entre a violação de regras que enquadram o exercício de uma atividade e a retribuição pela lesão de direito de autor.

O n. ${ }^{\circ} 1$ do artigo $205 .^{\circ}$ pretende proteger os produtores contra a prensagem ou a duplicação não autorizada de fonogramas e videogramas, nos termos do artigo $143 .^{\circ}$. A ilicitude consiste na violação de deveres de informação à Inspeção-Geral das Atividades

\footnotetext{
${ }^{19}$ SILVa Dias, Augusto. Direito das Contraordenações..., p. 55.

${ }^{20}$ Silva Dias, Augusto. Direito das Contraordenações..., p. 55.

21 SILVA Dias, Augusto. Direito das Contraordenações..., p. 40.

${ }^{22}$ SILVA DIAS, Augusto. Direito das Contraordenações..., p. 51.

${ }^{23}$ Sousa ANTUNES, Henrique. Da Inclusão do Lucro ..., pp. 634 e ss.
} 


\section{Revista IBERC}

v.2, n. 1, p. 01-23, jan.-abr./2019

www.responsabilidadecivil.org

Culturais. Trata-se, pois, da regulação de uma atividade económica e, nessa medida, adequadamente submetida à competência do regime das contraordenações.

O n. ${ }^{\circ} 2$ do artigo $205 .^{\circ}$ tem um sentido diverso. Nos termos da norma, constitui contraordenação punível a falta de identificação do autor e/ou da obra considerados. Esta omissão ofende o núcleo do direito de autor, esvazia o poder jurídico que a lei atribuiu ao criador intelectual da obra. Silenciada a autoria, onde está o criador? $\mathrm{O}$ alcance essencialmente subjetivo, individual, da lesão é evidente, nesta se descobrindo a negação de um traço que singulariza a natureza humana. Na criação literária, científica ou artística reconhece-se a pessoa. Negada a sua identidade, negada é a pessoa. Recuperando as sugestivas palavras de David G. OWEN, pronunciando-se a respeito da condenação em punitive damages (tradução nossa):

O estabelecimento de bolhas de direitos, com fronteiras definidas por lei, atribui a cada pessoa a sensação de que pode, com segurança, atuar no âmbito da sua bolha privada sem o constrangimento de uma interferência alheia. Quando uma pessoa viola intencionalmente a bolha de direitos de outrem, "rouba" a autonomia da vítima, deixando transparecer a ideia de que o ladrão é mais merecedor do que a vítima. Se a usurpação da autonomia (...) não fosse submetida a penalidades em adição à restituição dos bens roubados (indemnização compensatória), a emenda da transação seria incompleta ${ }^{24}$.

A competência das penas privadas não encontra assento no argumento histórico e formal da sua inclusão no Código Civil. Ela é expressão da convocação genérica do direito civil à retribuição dos comportamentos entre particulares que, sem merecerem a reprovação do direito penal, justificam a repreensão do comportamento, satisfazendo a necessidade de reafirmação da dignidade do ofendido perante o lesante e as exigências de prevenção geral e especial da conduta. Converter a Administração em beneficiária de uma coima num âmbito que excede a sua competência é consagrar uma solução manifestamente ilegítima e lesiva da dignidade do lesado.

Considerando os fins do direito penal e a estrutura bilateral do direito civil, revela-se inadequado substituir as penas criminais por sanções punitivas de direito privado. Diversamente sucede a respeito das contraordenações. Falta-Ihes a ressonância ética das sanções que a "coisificação" do direito subjetivo alheio impõe. Nesse sentido, escreve, exemplarmente, António PINTO MONTEIRO:

É de sublinhar, entretanto, a acentuação que se vem colocando num sistema sancionatório privatístico, contraposto a um controlo público, seja este atuado através de sanções do foro penal ou do foro administrativo, pois só o primeiro

\footnotetext{
${ }^{24}$ The Moral Foundations of Punitive Damages. Alabama Law Review, vol. 40 (1988-1989), p. 711.
} 
dará plena guarida tanto às exigências da despenalização como às de evitar uma crescente publicização da vida social, pela via do direito administrativo. $E$ se é certo que a abolição do direito penal, na esteira de Hulsman, confiando aos particulares e à sociedade civil a gestão dos conflitos de interesses, não passa de uma utopia, isso não impede, como a doutrina penalística vem sublinhando, dentro de uma política contrária ao ímpeto criminalizante do legislador moderno - preocupada, além do mais, com os efeitos perniciosos da estigmatização individual -, que uma eficaz estratégia de descriminalização passe por um sistema sancionatório civilístico ${ }^{25}$.

É certo que o regime de indemnização dos danos não patrimoniais no direito português pode trazer algumas incertezas a um regime geral de penas privadas. Eis o que justificaria a previsão legal desse regime, permitindo recuperar o sentido original da indemnização dos danos não patrimoniais, vocacionada para a compensação.

Enfim, «o legislador deve redescobrir a pena privada sem constrangimentos, tão-só motivado pela superior adequação da medida em relação à tutela contraordenacional, considerando a natureza dos interesses em juízo» ${ }^{26}$. Em defesa dessa ampla competência, propõe André TUNC a legitimidade da pena privada «sempre que se depare com a vontade (do legislador, do juiz ou mesmo de um contraente) de punir, de reprimir, sem recorrer aos meios do direito penal clássico, e pela simples atribuição de uma soma de dinheiro (ou excecionalmente de um bem) à vítima de um comportamento ilícito» (tradução de António PINTO MONTEIRO) ${ }^{27}$.

De novo, o direito europeu, denunciando, agora, a esquizofrenia que a proibição da condenação em punitive damages, antes declarada, revela. Num plano geral, são vários os atos normativos que, sem uma referência expressa a sanções punitivas privadas, requerem a imposição de medida efetivas, proporcionadas e dissuasivas ${ }^{28}$. Merece, em especial, relevo a Diretiva 2006/54/CE, de 5 de julho de 2006, relativa à aplicação do princípio da igualdade de oportunidades e igualdade de tratamento entre homens e mulheres em domínios ligados ao emprego e à atividade profissional (reformulação), onde a prossecução de um fim autónomo de prevenção aparece associada à indemnização ${ }^{29}$.

Nos termos do artigo 18. ${ }^{\circ}$

\footnotetext{
${ }^{25}$ Cláusula Penal e Indemnização. Coimbra: Almedina, 1990, p. 668, nota 1537 da p. 663. Ver, ainda, as considerações e os exemplos de direito comparado do parágrafo anterior ao texto citado.

${ }^{26}$ SOUSA ANTUNES, Henrique. Da Inclusão do Lucro ..., p. 629.

27 La Pena Privata nel Diritto Francese. In: Busnelli, Francesco D.; ScAlfi, Gianguido (Org.). Le Pene Private. Milano: Giuffrè Editore, 1985, p. 350 (o texto original é citado no nosso Da Inclusão do Lucro ..., p. 629). Encontra-se a tradução em PinTo Monteiro, António. Cláusula Penal ..., p. 666, nota 1537 da p. 663.

${ }^{28}$ Ver KoCH, Bernhard A. Punitive Damages in European Law. In: KozIOL, Helmut; WILCox, Vanessa (Org.). Punitive Damages: Common Law and Civil Law Perspetives. Wien/New York: Springer, 2009, pp. 200 e ss.

${ }_{29}$ Publicada no “Jornal Oficial da União Europeia" L 204, de 26 de julho de 2006, pp. 23 a 36.
}

Revista IBERC, Minas Gerais, v.2, n.1, p. 01-23, jan.-abr./2019 
Os Estados-Membros introduzem na respetiva ordem jurídica interna as medidas necessárias para garantir a existência de uma real e efetiva indemnização ou reparação, conforme os Estados-Membros o determinem, pelos prejuízos e danos sofridos por uma pessoa lesada em virtude de um ato discriminatório em razão do sexo, de uma forma que seja dissuasiva e proporcional aos prejuízos sofridos. Tal indemnização ou reparação não estará sujeita à fixação prévia de um limite máximo, salvo nos casos em que o empregador possa provar que o único prejuízo sofrido por um candidato na sequência de uma discriminação na aceção da presente diretiva seja a recusa em tomar em consideração a respetiva candidatura ${ }^{30}$.

Mais incisivamente, no direito europeu são paradigmas de um reconhecimento expresso do alcance punitivo do direito civil o artigo $28 .^{\circ}$, n. $^{\circ} 1$, da Diretiva 2004/109/CE do Parlamento Europeu e do Conselho, de 15 de dezembro de 2004, relativa à harmonização dos requisitos de transparência em informações respeitantes aos emitentes cujos valores mobiliários estão admitidos à negociação num mercado regulamentado, e o artigo $18 .^{\circ}, \mathrm{n} .^{\circ} 2$, do Regulamento (CE) n. ${ }^{\circ}$ 1768/95 da Comissão, de 24 de julho de 1995, em matéria do regime comunitário de proteção das variedades vegetais ${ }^{31}$.

Entretanto, a este respeito, tem importância a jurisprudência do Tribunal Europeu dos Direitos do Homem, que, fundada no conceito de "reparação razoável" (artigo $41 .^{\circ}$ da Convenção Europeia dos Direitos do Homem), parece ter construído um modelo de indemnização orientado para o restabelecimento da dignidade humana violada $\mathrm{e}$, de igual modo, a prevenção geral e especial da ilicitude. Observe-se que o sistema é, por definição, fundado em direitos das pessoas, sem prejuízo do desígnio coletivo que a anima. Ou seja, é superável o constrangimento de quaisquer argumentos utilitaristas, pois, deste modo, revela-se desnecessário o direito público para a reafirmação da dignidade da pessoa humana e a justa ordenação dos comportamentos entre particulares.

Pretende a maioria que a reparação razoável referida se contém no alcance da indemnização, designadamente por danos não patrimoniais. O juízo parece, no entanto, silenciar uma realidade manifestamente diversa. Em Cyprus v. Turkey (2014) encontram essas reflexões apoio.

Desde logo, interessa destacar a afirmação pelo Tribunal da existência de uma relação de condicionalidade entre a natureza individual dos danos e a reparação razoável. Se a medida é aplicada num litígio entre Estados, como sucedia, são necessariamente beneficiárias as vítimas individuais. O sistema está desenhado segundo o reconhecimento de que a sanção colhe o seu fundamento na dimensão individual da ofensa aos direitos do homem. O Estado de

\footnotetext{
${ }^{30}$ Os precedentes normativos e judiciais deste regime reforçam o entendimento sobre a dimensão extraindemnizatória da solução (ver SouSA ANTUNES, Henrique. Da Inclusão do Lucro ..., pp. 640 e ss.).

${ }_{31}$ Publicados no "Jornal Oficial da União Europeia", respetivamente, L 390, de 31 de dezembro de 2004 , pp. 38 a 57, e L 173, de 24 de julho de 1995, pp. 14 a 21.
} 


\section{Revista IBERC}

v.2, n. 1, p. 01-23, jan.-abr./2019

www.responsabilidadecivil.org

que o lesado é cidadão não tem legitimidade para receber a quantia atribuída, pois não é titular do direito violado. Lê-se, na versão original do Acórdão: (...) it must be always kept in mind that, according to the very nature of the Convention, it is the individual, and not the State, who is directly or indirectly harmed and primarily "injured" by a violation of one or several Convention rights. Therefore, if just satisfaction is afforded in an inter-State case, it should always be done for the benefit of individual victims (§ 46). Se na reparação razoável identificarmos uma pena de natureza privada, descobre-se melhor exemplo sobre a impropriedade das contraordenações que sancionam a violação de bens jurídicos individuais?

Em litígio, a reparação pedida pelo Estado cipriota à Turquia pelo desaparecimento de 1456 pessoas e pelas violações de direitos humanos praticadas sobre cidadãos cipriotas gregos, na península de Karpas, entre 1974 e 2001. O Tribunal reiterou a posição anterior assumida no caso Varnava and Others v. Turkey (2009), declarando que o critério de decisão é a equidade. Segundo a instância, a equidade assegura a flexibilidade e a ponderação exigíveis à apreciação adequada de todas as circunstâncias do caso, compreendendo, além da posição do requerente, o contexto geral em que a ofensa foi praticada. A atribuição da reparação tem como objetivo exprimir que a lesão sofrida pelo requerente foi a consequência da lesão de um direito humano fundamental e denunciar com a maior amplitude possível a severidade da ofensa.

É certo que o Tribunal associa a reparação atribuída à compensação de danos não patrimoniais (30 milhões de euros destinados aos familiares das pessoas falecidas e 60 milhões de euros aos residentes lesados, ou seus herdeiros, da península de Karpas). Razão tem, no entanto, Paulo PINTO DE AlbuQUerque na sua declaração de voto concordante: o Tribunal condenou o Estado requerido em punitive damages, em penas de natureza privada. Vários factos permitem dizê-lo. Entre outros: as vítimas em Karpas não foram identificadas nem são identificáveis; a prescrição vedaria a atribuição de uma indemnização aos familiares das pessoas desaparecidas se aqueles tivessem agido individualmente; a ausência de critérios sobre a medida da repartição da indemnização entre os lesados ou os seus herdeiros e a incerteza sobre a correspondência entre as vítimas efetivas e os destinatários das indemnizações ${ }^{32}$. Acrescentaríamos: a reparação abrange, ainda, as quantias correspondentes à aplicação de impostos sobre as verbas fixadas.

Em suma, embora o artigo $41 .^{\circ}$ da Convenção Europeia dos Direitos do Homem limite a condenação em reparação razoável à impossibilidade de o direito interno da Alta Parte Contratante se revelar suficiente para obviar às consequências da violação, essa insuficiência verifica-se na ausência de satisfação das necessidades de prevenção e de punição justificadas

${ }^{32} \mathrm{Pp} .30$ e 31.

Revista IBERC, Minas Gerais, v.2, n.1, p. 01-23, jan.-abr./2019 


\section{Revista IBERC}

v.2, n. 1, p. 01-23, jan.-abr./2019

www.responsabilidadecivil.org

pelas circunstância do caso concreto. Assim o entende, e a nosso ver bem, Paulo PINTO DE ALBUQUERQUE ${ }^{33}$.

Segundo este Juiz, a decisão segue uma orientação genérica do Tribunal Europeu dos Direitos do Homem. A condenação em punitive damages recebe a seguinte tipologia: a violação grave de direitos humanos protegidos pela Convenção ou pelos Protocolos adicionais, designadamente pela reiteração ou continuidade da prática; incumprimento prolongado e intencional de uma condenação do Tribunal; o cerceamento severo, ou a ameaça desse cerceamento, aos direitos humanos do requerente com o objetivo de evitar, dificultar ou restringir o acesso ao Tribunal ou a comunicação do Tribunal com o requerente ${ }^{34}$.

Finalmente, e ainda segundo Paulo PINTO DE AlbuQUerque, na condenação em punitive damages o Tribunal age de acordo com o princípio da proporcionalidade, respeitando os fatores seguintes: a gravidade objetiva da ofensa, o grau de dolo ou negligência do lesante, a extensão da lesão causada ao requerente ou a terceiros, os lucros ilícitos obtidos pelo agente ou terceiros e a probabilidade de inexecução do direito ofendido.

Satisfazendo os requisitos de legalidade e de proporcionalidade aplicáveis, princípios de que o direito civil não se pode dissociar, a solução parece justificada no direito português. Aliás, entre nós, a relevância da dimensão coletiva da lesão permitiu ao legislador ensaiar uma nova abordagem ao dever de indemnizar. Desde logo, para obter um nível ótimo de prevenção, acolhendo a possibilidade de fixação de uma quantia global (artigo 22. ${ }^{\circ}$, n. ${ }^{\circ} 2$, da Lei n. ${ }^{\circ} 83 / 95$, de 31 de agosto). Nas palavras de Miguel TEIXEIRA DE SOUSA:

(...) o regime da ação popular, quando define uma indemnização global que se destina a ser repartida pelos lesados, (...) preocupa(-se) mais em evitar que o lesante possa extrair alguma vantagem do facto danoso do que em assegurar que cada um desses lesados seja realmente indemnizado pela exata medida do prejuízo sofrido. A indemnização global procura distribuir pelos lesados os ganhos do lesante, ainda que disso possa resultar alguma violação da justiça corretiva, pois que essa distribuição não pode assegurar que todo o dano sofrido seja efetivamente ressarcido pelo seu exato montante. Para a quantificação da indemnização global utiliza-se mais o ganho (global) obtido pelo lesante do que o prejuízo (igualmente global) por ele infligido, o que significa que na sua quantificação não se segue o critério da reconstituição da situação hipotética que se encontra estabelecido no art. 562. ${ }^{\circ} \mathrm{CC}^{35}$.

O espaço revela-se, pois, propício à reflexão sobre a introdução de penas privadas.

Considerando, no entanto, a necessidade de prevenir práticas disseminadas na sociedade que escapam, geralmente, à justiça coletiva, a analogia, até por maioria de razão,

\footnotetext{
${ }^{33}$ P. 33.

${ }^{34}$ P. 36

${ }^{35}$ A Legitimidade Popular na Tutela dos Interesses Difusos. Lisboa: Lex, 2003, pp. 169 e s.
} 


\section{Revista IBERC}

v.2, n. 1, p. 01-23, jan.-abr./2019

www.responsabilidadecivil.org

determina a mesma oportunidade de reforma nas ações individuais. Estas servem, ainda, de paradigma de um modelo tradicional. Nesse sentido, veja-se o que dispõe o princípio 31 da Recomendação da Comissão Europeia de 11 de junho de 2013, atrás citada:

Proibição de indemnizações punitivas - A indemnização atribuída às pessoas singulares ou coletivas lesadas em situação de dano em massa não deve exceder a compensação que teria sido atribuída se o direito tivesse sido reclamado através de ações individuais. Devem ser proibidas, em especial, as indemnizações punitivas, que conduzam a uma sobrecompensação do dano sofrido a favor da contraparte.

\section{PROPOSTAS DE REFORMA DO CÓDIGO CIVIL PORTUGUÊS}

Tomando como referência a dissociação do resgate do lucro ilícito relativamente ao reconhecimento da legitimidade da pena privada, ensaia-se uma alteração legislativa sobre os efeitos da responsabilidade civil no direito português ${ }^{36}$. Eis, então, os termos da proposta.

Desde logo, a revisão do artigo $564 .{ }^{\circ}$, n. $^{\circ} 1$, do Código Civil, que deveria dispor nos termos seguintes: «O dever de indemnizar compreende não só o prejuízo causado, como os benefícios subtraídos ao lesado e os lucros obtidos pelo lesante em consequência da lesão».

Depois, a inclusão de um preceito novo no regime da responsabilidade civil:

Artigo $483 .^{\circ}$ - A Pena pecuniária

1. Em caso de violação ilícita e dolosa do direito de outrem, o Tribunal, a requerimento do lesado, pode condenar o autor da lesão numa pena pecuniária que acresce à indemnização, fixada em função da gravidade da ofensa, dos benefícios recebidos pelo lesante com a prática do facto e da reiteração da conduta, ponderando, ainda, a situação económica das partes e as demais circunstâncias do caso concreto.

2. A pena tem como limite o triplo do proveito económico obtido pelo autor com a prática do facto ilícito ou, se este for superior, o triplo do valor dos danos causados.

3. Se o facto ilícito constituir crime é inaplicável a pena pecuniária prevista neste artigo.

4. O montante da pena destina-se ao lesado.

5. O pagamento da pena não pode estar coberto por um seguro.

Afigura-se que, de forma diversa do que sucede com o resgate do lucro ilícito, a previsão da pena pecuniária restringe o seu alcance à responsabilidade civil extraobrigacional

\footnotetext{
${ }^{36} \mathrm{Em}$ análise crítica às opções de reforma do direito francês, salienta-se a equívoca associação entre a restituição do lucro e a punição do lesante [vejam-se, por exemplo, VINEY, Geneviève; JouRDAIN, Patrice; CARVAL, Suzanne. Les effets de la responsabilité, 4e édition. In: GHEStin, Jacques. Traité de droit civil. Paris, 2017, pp. 25 e ss., e Le DANTEC, Aude; ThouÉment, Amélie. L'amende civile. In: PignARRE, LouisFrédéric (Org.). La réforme du droit de la responsabilité (Actes du colloque du 25 novembre 2016 Faculté de Droit et de Science politique. Université de Montpellier). Université de Montpellier, s/d, pp. 199 e ss.].
} 


\section{Revista IBERC}

v.2, n. 1, p. 01-23, jan.-abr./2019

www.responsabilidadecivil.org

e à responsabilidade obrigacional sem fonte negocial. Na verdade, pretendendo o credor de uma prestação contratual dispor desse remédio, deve recorrer à previsão de uma cláusula penal. A autonomia da vontade prevalece sobre a disciplina legal.

A solução que agora se propõe acolhe a emancipação de um direito privado punitivo, respeitando exigências de legalidade e de proporcionalidade, emergentes, designadamente, da Convenção Europeia dos Direitos do Homem ${ }^{37}$. O pressuposto da condenação acompanha a arquitetura detalhada das relações jurídico-privadas e, submetida a pena a limites máximos, a proposta assegura a prevenção de qualquer arbitrariedade que comprometa o respeito pela integridade do património das pessoas singulares ou coletivas.

Note-se que a certeza da solução é confortada pela restrição da pena pecuniária à lesão de direitos absolutos. Exclui-se a relevância da violação de disposições legais destinadas a proteger interesses alheios, pois aí, sem prejuízo do direito de indemnização que o artigo 483. ${ }^{\circ}$ do Código Civil atribua, há uma dimensão coletiva imbrincada na tutela dos interesses particulares que justifica o regime da mera ordenação social.

Em proveito da segurança jurídica, sacrifica-se, pois, o espaço autónomo desta modalidade de ilicitude, designadamente acerca da reparação de danos puramente patrimoniais. Nesse caso, a dimensão punitiva é, fundamentalmente, restringida à competência do direito penal ou do direito contraordenacional.

Silencia-se, ainda, o papel auxiliar das normas de proteção na condenação em sanção punitiva civil pela lesão de um direito alheio. Na verdade, embora esta segunda modalidade de ilicitude simplifique a determinação da responsabilidade pela violação de direitos absolutos («nem sequer é necessário que seja previsível a ocorrência de um dano”38), a pena privada, fundada, como vimos, na prevalência do bem jurídico individual, exige uma conexão imediata entre a conduta do agente e o direito subjetivo violado. $O$ desrespeito pela norma é incidental relativamente à imputação subjetiva da lesão. Fica, então, claro que o dolo deve ser aferido em

\footnotetext{
${ }^{37}$ Sobre uma análise recente do projeto de reforma da responsabilidade civil em França a esta luz, vejamse, por exemplo, RIAS, Nicolas. Les nouvelles fonctions de la responsabilité civile (regard français). In: MALlet-Bricout, Blandine (Org., sob a égide da Association Henri Capitant). Vers une réforme de la responsabilité civile française. Regards croisés franco-québecois. Paris: Dalloz, 2018, pp. 67 e ss., e VÉRON, Paul. Réflexions sur la faute lucrative dans l'avant projet de réforme de la responsabilité civile. In: PignaRRE, Louis-Frédéric (Org.). La réforme du droit de la responsabilité, cit., pp. 219 e ss.

${ }^{38}$ SINDE MONTEIRO, Jorge Ferreira. Responsabilidade por Conselhos, Recomendações ou Informações. Coimbra: Almedina, 1989, p. 240. De forma mais desenvolvida, escreve o autor: «Na maior parte das vezes, as pretensões indemnizatórias por violação de uma disposição legal destinada a proteger interesses alheios coexistem com as derivadas da lesão de direitos absolutos. Todavia, enquanto a ordem jurídica, ao conformar um direito como absolutamente protegido, apenas impõe a qualquer terceiro fazer o objetivamente possível a um homem médio para evitar o pôr em perigo desse direito, as disposições de proteção prescrevem formas de conduta bem concretas e determinadas, trazendo com isso para o lesado a vantagem de que a ilicitude do comportamento é mais fácil de comprovar» (p. 238).
}

Revista IBERC, Minas Gerais, v.2, n.1, p. 01-23, jan.-abr./2019 


\section{Revista IBERC}

v.2, n. 1, p. 01-23, jan.-abr./2019

www.responsabilidadecivil.org

relação ao direito absoluto violado e não ao incumprimento das normas de proteção, infração que permitiu a verificação do dano.

Em função do que se escreve, a cumulação de uma coima com uma pena pecuniária só se afigura ofender o princípio ne bis in idem se o regime das contraordenações for indevidamente aplicado à tutela de bens jurídicos predominantemente individuais, como o reconhecimento de um direito absoluto atesta. Há separação de águas.

A possibilidade de fixação da pena no triplo do valor de referência segue soluções que, com esse alcance generoso, o direito português desde já conhece. Veja-se o artigo $1320 .^{\circ}$ do Código Civil, a respeito de animais selvagens com guarida própria que hajam sido atraídos para guarida alheia com fraude ou artifício do terceiro: «(...) é este obrigado a entregá-los ao antigo dono, ou a pagar-lhe em triplo o valor deles, se Ihe não for possível restituí-los». Ou o artigo 246..$^{\circ}$ n. ${ }^{\circ}$, do Código do Trabalho: "Caso o empregador obste culposamente ao gozo das férias nos termos previstos nos artigos anteriores, o trabalhador tem direito a compensação no valor do triplo da retribuição correspondente ao período em falta, que deve ser gozado até 30 de abril do ano civil subsequente».

A proporcionalidade evidencia-se nos critérios que habilitam o julgador à fixação da pena e na moldura definida pelo legislador. Sem prejuízo do enquadramento da pena nos limites definidos pelo $\mathrm{n}^{\circ} 2$ da disposição proposta, a gravidade da ofensa, os benefícios do infrator e a reiteração do comportamento ilícito são circunstâncias que justificadamente, o julgador deve tomar em consideração na definição da sanção aplicável. A adequação da pena requer, ainda, a ponderação da situação económica das partes e das demais circunstâncias que se afigurem relevantes.

O projeto de reforma da responsabilidade civil em França, antes mencionado, prevê que a multa seja limitada ao décuplo do proveito económico obtido pelo agente com a prática do facto ilícito (artigo 1266-1, alínea 3). A norma circunscreve-se, porém, aos comportamentos dolosos ditados pela obtenção de um benefício económico com a ofensa (alínea 1). Nesse sentido, ainda que dúvidas possa haver acerca da bondade da multiplicação do valor de referência por 10, a escolha desse valor parece respeitar um critério de proporcionalidade ${ }^{39}$.

Considerando que a nossa proposta tem outra ambição, diverso será o enquadramento. Neste contexto, tem especial relevância o exemplo do direito do Québec, habilitando à condenação em dommages-intérêts punitifs a violação ilícita e intencional de um direito ou uma liberdade reconhecida pela Carta dos direitos e liberdades da pessoa (1975 -

\footnotetext{
39 Pronuncia-se no sentido da adequação da proposta JUEN, Emmanuelle. Vers la consécration des dommages-intérêts punitifs en droit français. Présentation d'un regime. Revue trimestrielle de droit civil, juillet-septembre 2017, pp. 580 e ss.
} 


\section{Revista IBERC}

v.2, n. 1, p. 01-23, jan.-abr./2019

www.responsabilidadecivil.org

artigo $\left.49 .{ }^{\circ}\right)^{40}$. O regime está, pois, desvinculado de uma intenção lucrativa do agente. Considere-se, ainda, que o lucro pode ser inferior ao dano. Assim, parecendo-nos que é ajustado ligar o valor de referência às circunstâncias do caso concreto, de modo a evitar a ineficácia gerada pela arbitrariedade da fixação de quantias abstratas, o dano pode desempenhar essa função ${ }^{41}$. Afinal, a punição tem como objeto comportamentos dolosos, havendo na antecipação do dano um critério que permite vincular a medida da pena à medida da culpa e às exigências de prevenção (em paralelismo com o disposto no artigo $71 .^{\circ}, \mathrm{n} .^{\circ} 1$, do Código Penal sobre as penas criminais). Esta relação desenha-se, ainda, na condenação em punitive damages no direito norte-americano, restringida agora à multiplicação por um dígito em ensaios de reconstrução da legitimidade constitucional da figura ${ }^{42}$.

Cremos que se revela bem fundada a opção pela proibição da contratação de um seguro destinado a cobrir o pagamento daquela sanção. Só a proibição do seguro garante, com efetividade, os efeitos retributivo e preventivo que andam associados à condenação em pena privada. É solução que se descobre no projeto de reforma do Código Civil francês, citado $^{43}$.

A previsão legal da pena pecuniária, a competência do juiz, a imposição de limites à condenação, a subsidiariedade em relação ao direito penal são escolhas que resguardam a solução das controvérsias que a utilização de punitive damages no direito norte-americano convoca $^{44}$. Reclama-se, porém, a atribuição da quantia punitiva ao lesado, em congruência com a tese sobre a desconformidade das contraordenações com a sanção da lesão de bens jurídicos individuais e, retomando uma reflexão anteriormente desenvolvida, em convergência com o reconhecimento da legitimação da pena pelo dano.

Sobre o primeiro aspeto, há que salientar a diferença entre o direito das contraordenações e o direito penal. Escrevemos, então:

\footnotetext{
40 A título exemplificativo, descobre-se uma análise recente deste regime em LACROIX, Mariève. Les nouvelles fonctions de la responsabilité civile (regard québécois). In: MALLET-BRICOUT, Blandine (Org., sob a égide da Association Henri Capitant). Vers une réforme de la responsabilité civile française. Regards croisés franco-québecois, cit., pp. 79 e ss.

41 A utilização conjugada do lucro e do dano como padrões de limitação da pena permite obviar às objeções a um recurso, em exclusividade, ao critério do dano. Sabendo que a um proveito económico pode corresponder um dano substancialmente menor, uma pena vinculada aos ilícitos praticados com intenção lucrativa revelar-se-ia inoperante se limitada pelo valor do dano (neste sentido, JUEN, Emmanuelle, Vers la consécration des dommages-intérêts punitifs en droit français. Présentation d'un regime, cit., pp. 579 e ss.).

${ }^{42}$ Veja-se Sousa ANTUNES, Henrique. Da Inclusão do Lucro ..., pp. 109 e ss.

${ }^{43}$ Pela bondade dessa solução, veja-se, por exemplo, JUEN, Emmanuelle, Vers la consécration des dommages-intérêts punitifs en droit français. Présentation d'un regime, cit., pp. 575 e ss.

${ }^{44}$ Remete-se para o que escrevemos em Da Inclusão do Lucro ..., pp. 89 e ss.
} 


\section{Revista IBERC}

v.2, n. 1, p. 01-23, jan.-abr./2019

www.responsabilidadecivil.org

[...] objetar-se-á que o destino público da sanção é compatível com a satisfação do interesse do lesado, pois dessa premissa parte o direito penal. Sabendo que o movimento destinado a realçar o papel da vítima na ação penal e na definição da pena aplicável tem recebido amplo acolhimento e que à pena acolhe a reprovação moral do comportamento ilícito, a preferência do bem público é, na vigência do direito penal, dissemelhante do menoscabo do interesse privado. Noutro sentido se apura o direito da mera ordenação social. Que satisfação retira da coima o particular, se nem o crédito do agente é lesado? A questão revela-se, ainda, mais premente se o facto foi praticado por uma pessoa coletiva: esta pode repercutir o seu prejuízo sobre o património de terceiros. A satisfação do lesado é inadequada nos direitos em que o beneficiário da coima é uma pessoa diversa do ofendido, acentuando-se quando respeita a uma pessoa coletiva, a quem o facto não é subjetivamente imputável, e esta, pela sua natureza, dilui a lesão nas relações que estabelece com terceiros ${ }^{45}$.

Advoga-se, enfim, que converter o lesado em destinatário da quantia correspondente à pena pecuniária proporciona-lhe um enriquecimento injustificado. É outro o nosso juízo. O dano é causa dessa atribuição: na ofensa intolerável a bens jurídicos individuais só há verdadeira justiça corretiva com a satisfação que a aplicação da pena privada proporciona ao lesado ${ }^{46}$.

\section{CONCLUSÃO}

Com a aprovação do Código Civil português de 1966, o legislador anunciava a revisão dos efeitos da responsabilidade civil, graduando a medida da indemnização em função do juízo de censura ao comportamento do lesante. Escrevia João de Matos ANTUNES VARELA:

A ideia de afeiçoar o quantum da indemnização à culpa do agente, por imitação do que a legislação penal faz com as multas e outras sanções aplicáveis ao delinquente, era como que uma nota musical a que não ascendia a audição dos civilistas, completamente surdos a melodias desse estilo. É precisamente nesse ponto que o novo Código descreve uma viragem espetacular. Sem destruir a função essencialmente reparadora da responsabilidade civil, e não permitindo, por isso, que a indemnização a cargo do lesante alguma vez exceda o valor do dano, em vários textos relativos à extensão da indemnização se não desdenha de assinar ao instituto, embora subsidiariamente, um papel repressivo do facto ilícito ${ }^{47}$.

\footnotetext{
${ }^{45}$ SOUSA ANTUNES, Henrique. Da Inclusão do Lucro ..., pp. 632 e ss.

${ }^{46}$ Veja-se TIlburY, Michael, Reconstructing Damages. Melbourne University Law Review, vol. 27 (2003), pp. 713 e s., e o nosso Da Inclusão do Lucro ..., pp. 608 e ss.

${ }^{47}$ Rasgos Inovadores do Código Civil Português de 1966 em Matéria de Responsabilidade Civil. Coimbra, 1972, pp. 18 e s.
}

Revista IBERC, Minas Gerais, v.2, n.1, p. 01-23, jan.-abr./2019 


\section{Revista IBERC}

v.2, n. 1, p. 01-23, jan.-abr./2019

www.responsabilidadecivil.org

Cinquenta anos volvidos, outro fôlego crê-se exigível. A esse respeito, sintetizamos os pressupostos da proposta de reforma que agora se apresenta. Retoma-se, em grande medida, o que já noutros momentos se escreveu ${ }^{48}$ :

1. É tempo de chamar à responsabilidade civil extracontratual a restituição do lucro ilícito e de àquela atribuir a partilha de competências com o direito contraordenacional. É tempo, enfim, de repensar as fronteiras entre institutos do direito privado e entre este e o direito público;

2. Acerca da restituição do lucro, são manifestas as insuficiências do enriquecimento sem causa. Revela-se, ainda, inequívoca a artificialidade do recurso à gestão de negócios imprópria, e, porventura, os seus efeitos perversos;

3. Considera-se devida a entrega do lucro como um efeito da responsabilidade civil. Assim vem sucedendo no direito europeu. Esse dever encontra acolhimento na dimensão relacional do princípio geral estabelecido pelo legislador a respeito da obrigação de indemnização (artigo 562. ${ }^{\circ}$ ). A lei impõe ao lesante o dever de recriar a situação hipotética que a sua intervenção impossibilitou. Essa realidade alternativa tem, necessariamente, de compreender a posição do agente. Se o lesante obteve um benefício patrimonial com o seu comportamento, é uma ficção dizer-se que a restituição escapa à reconstituição desejada;

4. É bem verdade que o artigo $562 .^{\circ}$ delimita o devedor pela obrigação de reparação de um dano, o que, em última instância, privaria de fundamento a interpretação que, em razão da perspetiva relacional da obrigação de indemnização, nesta pretendesse incluir o resgate do lucro, se o lesado não sofreu nenhum prejuízo. Sucede, porém, que esse entendimento restringe o dano a uma dimensão patrimonial ou, pelo menos, silencia o reflexo que o lucro tem na esfera não patrimonial do lesado;

5. Temos defendido que se apura um dano não patrimonial relevante, e portanto indemnizável segundo o artigo $496 .^{\circ}$ do Código Civil, sempre que do sacrifício censurável de bens do lesado advém para terceiro um benefício económico;

6. A amplitude com que a indemnização dos danos não patrimoniais foi acolhida no direito português, adaptável à evolução das circunstâncias sociais, o fim de satisfazer o lesado que àquela é reconhecida, reagindo à infirmação do seu direito, a natureza do bem que é ofendido, o sentimento de justiça, deve habilitar o juiz, nesta sede, a restituir ao lesante as receitas líquidas imputáveis ao seu comportamento. Em situações de elevada censurabilidade, admite-se a aplicação do critério das receitas brutas;

48 SOUSA ANTUNES, Henrique. Das funções reconstitutiva e punitiva da responsabilidade civil extracontratual. In Cardoso Guedes, Agostinho; Pinto Oliveira, Nuno Manuel (Org.). Colóquio de Direito Civil de Santo Tirso - O Código Civil 50 anos depois: balanço e perspetivas, cit., pp. 502 e ss. 


\section{Revista IBERC}

v.2, n. 1, p. 01-23, jan.-abr./2019

www.responsabilidadecivil.org

7. As condições estão criadas para, em função do lucro obtido pelo autor do facto ilícito, rever o alcance da responsabilidade no respeito dos princípios que, representando uma vitória da civilização moderna, se converteram na sua ortodoxia. De qualquer forma, em razão da emergência de regimes diversos que incluem na indemnização a entrega do lucro ilícito a unidade do sistema jurídico justifica a revisão daquele conceito.

8. Exclui-se qualquer efeito punitivo no resgate do lucro. O lesante perde as vantagens que ilegitimamente adquiriu, nada mais. Somente se apura aquele efeito quando, desprezando o direito alheio, o agente coisificou a pessoa. Está, nesse caso, impedido de deduzir à restituição o custo económico dos fatores produtivos que integram a sua esfera jurídica, mas deve, porventura, mais;

9. O direito privado vigente desconhece uma cláusula punitiva geral. Há, porém, um importante traço de identidade nos casos previstos na lei, pois as sanções privadas que, a respeito das consequências da aplicação da responsabilidade civil, apresentam um efeito punitivo são legitimadas pelo dano. $O$ dano é a causa da sua estatuição, destinando-se o remédio, nuns casos a determiná-lo ou a preveni-lo, noutros a satisfazer o direito do lesado ao desagravo;

10. Verifica-se uma adesão da sanção criminal às características e finalidades da solenidade da repressão penal que, justificadamente, argumenta em favor da impropriedade do direito privado, limitado pela natureza bilateral ou relacional das sanções que utiliza;

11. Diversamente sucede a respeito do regime das contraordenações. A lata amplitude do direito de mera ordenação social constitui uma aplicação do princípio da subsidiariedade do direito penal. Em alcance injustificado. As sanções beneficiam a Administração sem curar da natureza essencialmente individual dos bens ofendidos. Urge repensar as fronteiras entre 0 direito de mera ordenação social e o direito privado;

12. Afigura-se que, de forma diversa do que sucede com o resgate do lucro ilícito, a previsão legal de uma pena pecuniária restringe o seu alcance à responsabilidade civil extraobrigacional e à responsabilidade obrigacional sem fonte negocial. Na verdade, pretendendo o credor de uma prestação contratual dispor desse remédio, deve recorrer à previsão de uma cláusula penal;

13. A previsão legal da pena pecuniária, a competência do juiz, a imposição de limites à condenação, a subsidiariedade em relação ao direito penal são escolhas que resguardam a solução ora enunciada das controvérsias que a utilização de punitive damages no direito norteamericano convoca. 


\section{Revista IBERC}

v.2, n. 1, p. 01-23, jan.-abr./2019

www.responsabilidadecivil.org

\section{REFERÊNCIAS}

Almeida Costa, Mário Júlio de. Direito das Obrigações, 12. ${ }^{a}$ edição. Coimbra: Almedina, 2009;

Antunes Varela, João de Matos. Rasgos Inovadores do Código Civil Português de 1966 em Matéria de Responsabilidade Civil. Coimbra, 1972;

GOMES, Júlio. Uma função punitiva para a responsabilidade civil e uma função reparatória para a responsabilidade penal. Revista de Direito e Economia, ano XV (1989), pp. 105-144;

JUEN, Emmanuelle. Vers la consécration des dommages-intérêts punitifs en droit français. Présentation d'un regime. Revue trimestrielle de droit civil, juillet-septembre 2017, pp. 565-585;

KoCH, Bernhard A. Punitive Damages in European Law. In: KozıoL, Helmut; WILcox, Vanessa (Org.). Punitive Damages: Common Law and Civil Law Perspectives. Wien/New York: Springer, 2009, pp. 197-209;

LACROIX, Mariève. Les nouvelles fonctions de la responsabilité civile (regard québécois). In: MALLET-BRICOUT, Blandine (Org., sob a égide da Association Henri Capitant). Vers une réforme de la responsabilité civile française. Regards croisés franco-québecois. Paris: Dalloz, 2018, pp. 79-94;

Le Dantec, Aude; ThouÉment, Amélie. L'amende civile. In: PIgnARRE, Louis-Frédéric (Org.). La réforme du droit de la responsabilité (Actes du colloque du 25 novembre 2016 - Faculté de Droit et de Science politique. Université de Montpellier). Université de Montpellier, s/d, pp. 199211 ;

Miranda Barbosa, Ana Mafalda Castanheira Neves de. Lições de Responsabilidade Civil. Cascais: Princípia, 2017;

OWEN, David G. The Moral Foundations of Punitive Damages. Alabama Law Review, vol. 40 (1988-1989), pp. 705-739;

Pinto de Albuquerque, Paulo. Comentário do Regime Geral das Contraordenações à luz da Constituição da República e da Convenção Europeia dos Direitos do Homem. Lisboa: UCE, 2011;

Pinto MonteIRo, António. Cláusula Penal e Indemnização. Coimbra: Almedina, 1990;

RIAS, Nicolas. Les nouvelles fonctions de la responsabilité civile (regard français). In: MALLETBRICOUT, Blandine (Org., sob a égide da Association Henri Capitant). Vers une réforme de la responsabilité civile française. Regards croisés franco-québecois. Paris: Dalloz, 2018, pp. 6377 ;

SILVA DIAS, Augusto. Direito das Contraordenações. Coimbra: Almedina, 2018 (reimpressão);

SINDE MONTEIRO, Jorge Ferreira. Responsabilidade por Conselhos, Recomendações ou Informações. Coimbra: Almedina, 1989; 


\section{Revista IBERC}

v.2, n. 1, p. 01-23, jan.-abr./2019

www.responsabilidadecivil.org

SOUSA ANTUNES, Henrique. Da Inclusão do Lucro llícito e de Efeitos Punitivos entre as Consequências da Responsabilidade Civil Extracontratual: a sua Legitimação pelo Dano. Coimbra: Coimbra Editora, 2011;

SOUSA ANTUNES, Henrique. Das funções reconstitutiva e punitiva da responsabilidade civil extracontratual. In CARDoso Guedes, Agostinho; PINTO OliveIRA, Nuno Manuel (Org.). Colóquio de Direito Civil de Santo Tirso - O Código Civil 50 anos depois: balanço e perspetivas. Coimbra: Almedina, 2017, pp. 489-504;

TEIXEIRA DE SOUSA, Miguel. A Legitimidade Popular na Tutela dos Interesses Difusos. Lisboa: Lex, 2003;

TILBURY, Michael, Reconstructing Damages. Melbourne University Law Review, vol. 27 (2003), pp. 697-723;

TUNC, André. La Pena Privata nel Diritto Francese. In: Busnelli, Francesco D.; ScAlfI, Gianguido (Org.). Le Pene Private. Milano: Giuffrè Editore, 1985, pp. 349-363;

VÉRON, Paul. Réflexions sur la faute lucrative dans l'avant projet de réforme de la responsabilité civile. In: PIGNARRE, Louis-Frédéric (Org.). La réforme du droit de la responsabilité (Actes du colloque du 25 novembre 2016 - Faculté de Droit et de Science politique. Université de Montpellier). Université de Montpellier, s/d, pp. 213-226;

VINEY, Geneviève; Jourdain, Patrice; Carval, Suzanne. Les effets de la responsabilité, 4e édition. In: GHESTIN, Jacques. Traité de droit civil. Paris, 2017.

Como citar: SOUSA ANTUNES, Henrique. Das funções reconstitutiva e punitiva da responsabilidade civil: propostas de reforma do Código Civil português. Revista IBERC, Minas Gerais, v. 2, n. 1, p. 01-24, jan.-abr./2019. 